\title{
Different sterilization and disinfection methods used for human tendons - a systematic review using mechanical properties to evaluate tendon allografts
}

Denes Farago ${ }^{1,2^{*}+}$, Blanka Kozma ${ }^{3+}$ and Rita Maria Kiss ${ }^{1,2+}$

\begin{abstract}
Background: It is important to know the biomechanical properties of an allograft. This is because when looking to do a transplant of a tendon, the tendon must have very similar biomechanical properties to the original tendon. To use tendon allografts, it is critical to properly sterilize the tendon before implantation. In past decades, several sterilization procedures have been used. This study aimed to systematically evaluate the existing literature to compare the values of failure load/ultimate strength and Young's modulus of elasticity of different sterilization methods on commonly used tendon allografts. Five major scientific literature databases (Web of Science, Science Direct, Scopus, PLOS ONE, Hindawi) and additional sources were used.

Results: Studies used had to show a particular sterilization method. Studies were identified to meet the following inclusion criteria: is a controlled laboratory study, gamma irradiation (dose reported), and other sterilization methods. Search for publications dated between 1991 and March 31st, 2020. The database search and additional sources resulted in 284 records. Two hundred thirty records eliminated during the screening for various reasons. The number of articles used in the final synthesis was 54 .

Conclusions: Identified sterilization methods (gamma irradiation, ethylene oxid, supercritical carbon dioxide (SCCO2), BioCleanse, Electron Beam) are offered as a catalog of potential methods.

As a result of the broadness of the present research, it provides an overview of sterilization methods and their effect on the mechanical properties (failure load and Young's modulus of elasticity) of tendons. It does not stand for the state-of-the-art of any single process. Based on a systematic literature review, we recommend freezing and gamma irradiation or electron beam at 14.8-28.5 kGy. These methods are effective at keeping or improving the (Continued on next page)
\end{abstract}

\footnotetext{
* Correspondence: farago@mogi.bme.hu

${ }^{\dagger}$ Denes Farago, Blanka Kozma and Rita Maria Kiss contributed equally to this work.

${ }^{1}$ Cooperation Research Center for Biomechanics, Faculty of Mechanical Engineering, Budapest University of Technology and Economics, Budapest, Hungary

${ }^{2}$ Department of Mechatronics, Optics and Mechanical Engineering Informatics, Faculty of Mechanical Engineering, Budapest University of Technology and Economics, Budapest, Hungary

Full list of author information is available at the end of the article
} 
(Continued from previous page)

mechanical properties, while fully sterilizing the inside and the outside of the tendon. Other sterilization method (ethylene oxide, supercritical carbon dioxide (SCCO2), BioCleanse) deteriorated the mechanical properties. These methods are not recommended.

Keywords: Tendon, Sterilization, Gamma, Ebeam, Ethylene oxide, SCCO2, Biocleanse, Mechanical properties

\section{Background}

In orthopedic reconstruction, the use of tendon allografts has become more widely accepted in recent years, especially in the anterior cruciate ligament reconstruction. There have been multiple studies conducted which back the use of tendon allografts. The benefits include reduced operation time, reduced donor site morbidity, and unaltered mechanics secondary to harvesting. Additionally, studies conducted on animals and humans have demonstrated that soft tissue allografts are statistically comparable to autografts on an anatomical and biomechanical basis [1-3].

Anterior cruciate ligament (ACL) reconstruction is a common procedure in orthopedic practice [4-6]. A critical decision to be made is the choice of graft. Despite autografts proving capable and displaying good outcomes, graft harvest can cause continual pain at the site of harvest and limit the range of motion. For this reason, a significant increase in allograft use can be seen in the last decade, and despite the higher costs, it remains a feasible choice, specifically in revision cases [4, 7-9]. In young patients, an increased rate of failure of allografts has been recorded. This mostly seems to be caused by the sterilization process, as some studies also reported increased failure rates when comparing fresh-frozen allografts and autografts $[1,6,10$ 12]. A couple of studies displayed more inferior results in sterilization compared with fresh-frozen allografts. Septic arthritis after ACL reconstruction has been reported as a risk factor for unsterilized allografts. Also, higher rates of postoperative infections have been reported when allografts were aseptically processed rather than irradiated allografts or autografts [13-15].

A potential complication of using allografts is the risk of disease transmission. Possible diseases include both infections from HIV, Hepatitis C, and bacterial infection from organisms $[10,16,17]$. Whilst the prevalence of the transmission of the disease via allograft tissue is minimal; the potential impact is high $[5,18]$. After multiple documented cases of sepsis and infection following ACL reconstruction using allografts, the bacterial transmission of diseases has come to the forefront. These cases were associated with non-irradiated tissue grafts [1921]. For this reason, an effort has been made to reduce the scarce but possibly disastrous occurrences of bacterial infection by using enhanced sterilization techniques $[10,22-25]$.
According to standards for tissue banking such as American Association of Tissue Banks (AATB) Standards [26] listed the following for tissue sterilization: radiation (gamma, electron beam and X-ray) and ethylene oxide. Both methods can kill all microorganisms and can be validated according to international standards (ISO documents) and use of biological indicators. WHO and Pharmacoepea accept both sterilization methods for tissues, as these are effective in killing microorganism.

\section{Aim of the study}

The present systematic literature review aims to identify and to categorize existing sterilization methods and their effects on the mechanical properties (failure load/ultimate tensile strength and Young's modulus of elasticity) of the tendons.

Combining the collected materials should allow us to investigate how different methods can differentiate between participant groups (tendon types) and which methods are more encouraging in research or clinical practice.

\section{Materials and methods \\ Search strategy \\ Identification of materials}

This systematic review was executed according to the PRISMA guidelines [27]. Five electronic databases were used (Web of Science, Science Direct, Scopus, PubMed, PloS ONE, and Hindawi) to search for publications dated between 1991 and March 31st, 2020. Key search terms used with Boolean conjunction included: tendon, allograft tendon, tendon sterilization, biomechanical testing, mechanical properties, and synonyms of these terms. The expressions were matched to each database (Table 1).

For example, a search strategy used for the Science Direct database is as follows. In the Advanced search, the following phrases were added in All fields: (allograft tendon OR tendon) AND (tendon sterilization OR ligament sterilization OR sterilization) AND (biomechanical properties OR mechanical properties OR modulus). The search was refined to journal publications. Publication dates were set from 2008, with the search performed on March 31st, 2020. This search in the Science Direct database yielded 82 records. Key search terms were identified and agreed upon by DF and RMK; electronic 
Table 1 Viewpoints and their inclusion criteria and exclusion criteria

\begin{tabular}{|c|c|c|}
\hline Viewpoints & Inclusion criteria & Exclusion criteria \\
\hline $\begin{array}{l}\text { Tendon irradiation and } \\
\text { mechanical test }\end{array}$ & $\begin{array}{l}\text { Studies that included tendon sterilization and mechanical } \\
\text { tests in their experimental processes. }\end{array}$ & $\begin{array}{l}\text { Studies which only included tendon sterilization method } \\
\text { without any type of mechanical tests. }\end{array}$ \\
\hline $\begin{array}{l}\text { Description of tendon } \\
\text { sterilization and } \\
\text { mechanical test }\end{array}$ & $\begin{array}{l}\text { Studies with a detailed explanation of the tendon } \\
\text { sterilization and mechanical test and the experimental } \\
\text { procedure that was completed. }\end{array}$ & $\begin{array}{l}\text { Studies without detail or incomplete descriptions of the } \\
\text { tendon irradiation and mechanical test and the } \\
\text { experimental procedures that were completed. }\end{array}$ \\
\hline Assessment of results & $\begin{array}{l}\text { Studies with unbiased results based on measurable } \\
\text { parameters. }\end{array}$ & $\begin{array}{l}\text { Studies with biased scoring/assessments of results, not (fully) } \\
\text { based on measurable parameters. }\end{array}$ \\
\hline
\end{tabular}

search and downloading of results were conducted by DF. Screening, eligibility check of materials, and data extraction were executed by DF, BK, and BS.

\section{Screening materials}

The associated materials were screened based on title and abstract, removing duplicate entries. The materials of unrelated topics, aims, or completely theoretical work was excluded. Proof of concept articles was not omitted.

\section{Eligibility check of materials}

Inclusion and exclusion criteria were determined to check for eligibility. Studies had to meet all the inclusion criteria to be included in the final synthesis (Table 1). Studies that either met an exclusion criterion or otherwise failed to meet inclusion criteria were excluded. These criteria were created to provide a quality assessment to a certain extent, i.e., the methods applied had to be well communicated, and the evaluation of the measurement results had to be objective. No additional quality assessment was carried out on the materials included.

\section{Data extraction}

In compliance with the objective of this research, the final overview of the types of sterilization was to extract relevant information on the assessment of mechanical properties. The data collected from the articles included a) author and date, b) type of tendon, c) type of sterilization, d) sterilization dose, and g) measured and calculated parameters such as failure load/ultimate tensile strength and Young's modulus of elasticity.

\section{Results}

The database search and additional sources resulted in 284 records (Figure 1, in Supplementary file). One hundred fifty-two records remained after the removal of duplicates and the records with missing or unavailable abstracts. The title and abstract screening eliminated 60 records because of being unfit articles. The 92 items which remained went through a full-text eligibility check. Thirty-eight publications were eliminated from the 92 publications for various reasons, including clinical case reports, publications not written in English, conference abstract, and book chapters. Eight papers were literature review articles related to sterilization methods. The review articles found had an aim and scope different from the present study. The number of articles used in the final synthesis was $54(n=54)$.

The following were the reasons for exclusion: several studies applied criteria outside of the scope of our definition of tendon irradiation and mechanical properties, e.g., effects of gamma radiation if the tendon was infected with HIV. If multiple studies described similar tendon irradiation with an equal measurement method and similar instrumentation for assessment, the newest publication was used (30 pieces). Several theoretical articles did not detail a specific measurement setup and were therefore excluded (32 pieces). Some articles used a biased scoring assessment (6 pieces), and a few articles had an unrelated aim of the study, e.g., clinical case (7 pieces).

\section{Type of sterilization}

These studies evaluated the effect of sterilization's type: non-sterilized and non-frozen tendons (fresh tendons) ([28-31]; Table 2), gamma irradiation ([28, 37-47]; Table 3), Supercritical carbon dioxide (SCCO2) ([28]; Table 4), Ethylene Oxide ([51]; Table 5), BioCleanse ([8, 32-34]; Table 6), Electron Beam (E-beam) ([31, 48, 49, 53, 54]; Table 7), Peracetic acid-ethanol in combination with low-dose gamma irradiation (PE-R) ([35]; Table 8), Hydrogen peroxide ([55]; Table 9) and chlorhexidine ([36]; Table 10). The structure of the tendons may be destroyed by sterilization, so the method used is important. The following subsections detailed these sterilization methods, and the section of conclusion compared the failure load and Young's modulus of elasticity results found in the literature.

\section{Non-sterilized tendon (fresh/control tendon)}

Four articles mention the fresh grafts, which did not receive any sterilization ([8, 28-36]; Table 2). After they were procured from human cadavers, they were placed in a saline solution and cooled until the measurement. In comparative studies, non-sterilized tendons are measured as a standard to be able to tell to what extent the sterilization method and dose change its properties. Baldini et al. [28] analyzed three groups of anterior and 
Table 2 Average result of failure load and Young's modulus of elasticity of non-sterilized and non-frozen tendons [8, 28-36]

\begin{tabular}{|c|c|c|c|c|}
\hline Type of tendon & Pieces & $\begin{array}{l}\text { Failure load (Standard } \\
\text { Deviation) } \\
\text { [N] }\end{array}$ & $\begin{array}{l}\text { Young's modulus of elasticity (Standard } \\
\text { Deviation) } \\
\text { [MPa] }\end{array}$ & Authors \\
\hline Peroneus longus & 14 & $2091.6(148.7)$ & $90.3(11.3)$ & \multirow[t]{2}{*}{ Aguila et al. } \\
\hline Peroneus brevis & 20 & $1485.7(209.3)$ & $82.4(19.0)$ & \\
\hline Anterior or posterior tibialis & 15 & $2427.3(682.8)$ & $75.4(30.0)$ & Baldini et al. \\
\hline Patellar tendons & 10 & - & $25.0(9.0)$ & $\begin{array}{l}\text { Suhodolcan } \\
\text { et al. }\end{array}$ \\
\hline $\begin{array}{l}\text { Human flexor digitorum } \\
\text { superficialis }\end{array}$ & 10 & $402.5(38.4)$ & $400.5(58.5)$ & Wei et al. \\
\hline Patellar tendon & 14 & - & $158.0(49)$ & Bechtold et al. \\
\hline Achilles & 10 & $3032(677)$ & $292.04(123.15)$ & Conrad et al. \\
\hline Tibialis anterior & 12 & $1665(291.3)$ & $19.9(4.7)$ & Schimizzi et al. \\
\hline Tibialis tendon & 10 & $606.73(283.52)$ & $213.13(98.86)$ & Elenes et al. \\
\hline Bone - patellar tendon - bone & 10 & $1741(304)$ & - & $\begin{array}{l}\text { Hoburg et al. } \\
\text { Hoburg et al. }\end{array}$ \\
\hline Human flexor tendons & - & $360.01(88.17)$ & $221.55(73.06)$ & Zhou et al. \\
\hline Patellar tendon & 8 & $1878(613)$ & - & Sobel et al. \\
\hline
\end{tabular}

posterior tibialis tendons. The results showed that the failure load and Young's modulus of elasticity of the fresh group are weaker than the gamma-irradiated and SCCO2 sterilized groups ([28]; Table 2). Aguila et al. [29] found that no differences were between the results of the failure load and Young's modulus of elasticity of the non-sterilized and the gamma-irradiated groups in peroneus brevis and peroneus longus ([29], Table 2). Suhodolcan et al. [30] also compared three groups (fresh, frozen, and cryopreserved) of the patellar tendon; they compared the results of the fresh group to the frozen and the cryopreserved ([30], Table 2). Wei et al. [31] found that the mechanical properties (failure load and Young's modulus of elasticity) of the fresh group were higher than in the gamma-irradiated group ([31]; Table 2 ). From the above results, it can be stated that the values of the failure load and Young's modulus of elasticity of sterilized tendons either did not change or decrease as a result of gamma and gamma-irradiated ([8, 28-36]; Table 2).

\section{Gamma irradiation}

Gamma radiation is one of the most common sterilization methods. This sterilization method is used by ten articles ([8, 29, 33, 34, 37-50]; Table 3). During radiation, two doses are distinguished, the low dose (bacterial dose) of 15-26 kGy and the high dose (viricidal dose) of 30-45 kGy [44, 47]. The dosage unit is Mrad or kGy, 1 Mrad = $10 \mathrm{kGy}$.

The temperature can influence the impact of irradiation. This is important for interpreting results that is why we should point out this further nuance. Typically, it is cooled to between $-20^{\circ} \mathrm{C}$ and $-80{ }^{\circ} \mathrm{C}$ prior to sterilization and the tendon temperature is kept down by dry ice using gamma radiation. However, one article [44] compares the properties of tendons irradiated at room temperature $\left(20^{\circ} \mathrm{C}\right)$ and those frozen in freezing $\left(-72^{\circ} \mathrm{C}\right)$, which states that weaker properties are obtained for fresh tendons irradiated at room temperature. The articles were split into two groups; in the first group, multiple doses were used ([37, 40, 46]; Table 3). In the second group, only one dose was used ([29, 38, 39, 41-43, 45]; Table 3). Balsly et al. [37] used two irradiation doses, where the absorbed dose is 18.3-21.8 kGy and 24-28.5 kGy. Four tendons (patellar, anterior tibialis, semitendinosus, and fascia lata) were examined. Before the irradiation the tendons were deepfreeze to $80{ }^{\circ} \mathrm{C}$ and during the sterilization were on dry ice. Based on the results, it could not be declared that the increasing dose value diminished or increased the failure load and Young's modulus of elasticity of the tendons [37]. Gut et al. [40] used four doses (25, 35, 50, $100 \mathrm{kGy})$ for the patellar tendon. Before the irradiation the tendons were deepfreeze to $-70{ }^{\circ} \mathrm{C}$ and during the sterilization were on dry ice. The failure load of the irradiated tendons deteriorated relative to the control group. With an increase in dose, the mechanical properties of the tendon improved to $35 \mathrm{kGy}$, and after that, they deteriorated [40]. In the article by Hangody et al. [46], the target doses were 21 and $42 \mathrm{kGy}$, and five different types of tendons were tested. Before the irradiation the tendons were deepfreeze to $-72{ }^{\circ} \mathrm{C}$ and during the sterilization were on dry ice. In the case of the $21 \mathrm{kGy}$ dose, the failure load and Young's modulus of elasticity 
Table 3 Average result of failure load and Young's modulus of elasticity of gamma-irradiated tendons [8, 29, 33, 34, 37-50]

\begin{tabular}{|c|c|c|c|c|c|}
\hline Type of tendon & $\begin{array}{l}\text { Irradiation } \\
\text { dose }\end{array}$ & Pieces & $\begin{array}{l}\text { Failure load(Standard } \\
\text { Deviation) }[\mathrm{N}]\end{array}$ & $\begin{array}{l}\text { Young's modulus of elasticity (Standard } \\
\text { Deviation) [MPa] }\end{array}$ & Authors \\
\hline Peroneus longus & $1.5-2.5 \mathrm{Mrad}$ & 14 & $2122.8(380.0)$ & $94.8(21.0)$ & \multirow[t]{2}{*}{ Aguila et al. } \\
\hline Peroneus brevis & $1.5-2.5 \mathrm{Mrad}$ & 20 & $1318.4(296.9)$ & 72.5 (16.6) & \\
\hline Patellar tendon & 18.3-21.8 kGy & 9 & $2410(1100)$ & $88.11(26.9)$ & \multirow[t]{8}{*}{ Balsly et al. } \\
\hline Patellar tendon & 24.0-28.5 kGy & 9 & $2410(930)$ & $72.44(21.30)$ & \\
\hline Anterior tibialis & 18.3-21.8 kGy & 10 & $2890(720)$ & $328.47(37.12)$ & \\
\hline Anterior tibialis & $24.0-28.5$ kGy & 10 & $2420(330)$ & $309.66(56.67)$ & \\
\hline Semitendinosus & 18.3-21.8 kGy & 8 & $1010(360)$ & $369.08(122.47)$ & \\
\hline Semitendinosus & 24.0-28.5 kGy & 10 & $1230(380)$ & 410.08 (98.86) & \\
\hline Fascia lata & 18.3-21.8 kGy & 10 & $460(140)$ & $366.27(87.38)$ & \\
\hline Fascia lata & 24.0-28.5 kGy & 10 & $420(190)$ & 238.51 (113.43) & \\
\hline $\begin{array}{l}\text { Anterior or posterior tibialis } \\
\text { (young) }\end{array}$ & $1.48-1.80 \mathrm{Mrad}$ & 10 & 3062 (699) & - & \multirow[t]{3}{*}{$\begin{array}{l}\text { Greaves } \\
\text { et al. }\end{array}$} \\
\hline $\begin{array}{l}\text { Anterior or posterior tibialis } \\
\text { (middle) }\end{array}$ & $1.48-1.80 \mathrm{Mrad}$ & 13 & 2729 (995) & - & \\
\hline $\begin{array}{l}\text { Anterior or posterior tibialis } \\
\text { (old) }\end{array}$ & $1.48-1.80 \mathrm{Mrad}$ & 10 & 3004 (603) & - & \\
\hline $\begin{array}{l}\text { Flexor digitorum } \\
\text { superficialis }\end{array}$ & 25 kGy & 10 & $335.96(28.32)$ & $357.72(43.97)$ & \multirow[t]{2}{*}{ Ren et al. } \\
\hline $\begin{array}{l}\text { Flexor digitorum } \\
\text { superficialis }\end{array}$ & $\begin{array}{l}25 \mathrm{kGy} \text { (freeze } \\
\text { thaw) }\end{array}$ & 10 & $287.41(23.20)$ & 346.95 (69.09) & \\
\hline Achilles & $18-24$ kGy & 10 & $3572.54(393.57)$ & $181.7(24.05)$ & \multirow{10}{*}{$\begin{array}{l}\text { Hangody } \\
\text { et al. }\end{array}$} \\
\hline Achilles & $38-46$ kGy & 10 & 392.01 (180.91) & $134.75(15.07)$ & \\
\hline Quadriceps & 18-24 kGy & 10 & $3184.32(101.62)$ & $302.96(45.71)$ & \\
\hline Quadriceps & $38-46$ kGy & 10 & $3464.35(462.45)$ & $192.28(51.88)$ & \\
\hline Semitendinosus + gracilis & 18-24 kGy & 10 & $2310.32(561.2)$ & $248.93(14.43)$ & \\
\hline Semitendinosus + gracilis & $38-46$ kGy & 10 & $2271.96(651.12)$ & $213.88(20.28)$ & \\
\hline Tibialis anterior & $18-24$ kGy & 10 & $3107.76(606.41)$ & $327.93(44.31)$ & \\
\hline Tibialis anterior & $38-46$ kGy & 10 & $2678.96(181.45)$ & $375.15(67.84)$ & \\
\hline Peroneus longus & $18-24$ kGy & 10 & $2631.81(297.94)$ & $284.84(16.03)$ & \\
\hline Peroneus longus & $38-46$ kGy & 10 & $2291.71(523.76)$ & $333.11(79.11)$ & \\
\hline Patellar tendon & $4 \mathrm{Mrad}$ & 16 & $1884(330)$ & - & $\begin{array}{l}\text { Rasmussen } \\
\text { et al. }\end{array}$ \\
\hline Achilles & $1.5-2.5 \mathrm{Mrad}$ & 10 & $1972(558)$ & $129.48(53.22)$ & $\begin{array}{l}\text { Conrad } \\
\text { et al. }\end{array}$ \\
\hline Tibialis anterior & $20-26$ kGy & 12 & $1671.9(290.2)$ & $22.6(5.9)$ & $\begin{array}{l}\text { Schimizzi } \\
\text { et al. }\end{array}$ \\
\hline Tibialis tendon & $17.1-21$ kGy & 10 & $597.09(280.32)$ & $179.02(73.13)$ & Elenes et al. \\
\hline $\begin{array}{l}\text { Bone - patellar tendon - } \\
\text { bone }\end{array}$ & 25 kGy & 10 & $1009(400)$ & - & \multirow{2}{*}{$\begin{array}{l}\text { Hoburg } \\
\text { et al. } \\
\text { Hoburg } \\
\text { et al. }\end{array}$} \\
\hline $\begin{array}{l}\text { Bone - patellar tendon - } \\
\text { bone }\end{array}$ & 34 kGy & 10 & $1073(617)$ & - & \\
\hline
\end{tabular}

Table 4 Average result of failure load and Young's modulus of elasticity of sterilized tendons with supercritical carbon dioxide [28]

\begin{tabular}{|c|c|c|c|c|}
\hline Type of tendon & Pieces & $\begin{array}{l}\text { Failure load(Standard Deviation) } \\
\text { [N] }\end{array}$ & $\begin{array}{l}\text { Young's modulus of elasticity (Standard } \\
\text { Deviation) } \\
\text { [MPa] }\end{array}$ & Authors \\
\hline $\begin{array}{l}\text { Anterior or posterior } \\
\text { tibialis }\end{array}$ & 11 & $2450.3(576.8)$ & $91.9(30.2)$ & $\begin{array}{l}\text { Baldini } \\
\text { et al. }\end{array}$ \\
\hline
\end{tabular}


Table 5 Average result of failure load and Young's modulus of elasticity of sterilized tendons with ethylene oxide [51]

\begin{tabular}{|c|c|c|c|c|}
\hline $\begin{array}{l}\text { Type of } \\
\text { tendon }\end{array}$ & Pieces & $\begin{array}{l}\text { Failure } \\
\text { load(Standard } \\
\text { Deviation) [N] }\end{array}$ & $\begin{array}{l}\text { Young's modulus of } \\
\text { elasticity (Standard } \\
\text { Deviation) } \\
\text { [MPa] }\end{array}$ & Authors \\
\hline $\begin{array}{l}\text { Patellar } \\
\text { tendon }\end{array}$ & 14 & - & $143.0(67.0)$ & $\begin{array}{l}\text { Bechtold } \\
\text { et al. }\end{array}$ \\
\hline
\end{tabular}

of tendons improved versus the frozen group. In the case of the $42 \mathrm{kGy}$ dose, the mechanical properties of some grafts improved, and others deteriorated [46].

In the second group, the effect of gamma irradiation was examined compared to the control group. The values between $14.6-40 \mathrm{kGy}$ radiation dose were examined. In two cases $[39,42]$, the gamma radiation improved the failure load and Young's modulus of elasticity of the tendons. Weber et al. used a $15-25 \mathrm{kGy}$ irradiation dose for the Achilles tendon [42]. Curran et al. [39] used a $20 \mathrm{kGy}$ irradiation dose for the patellar tendon. Before the irradiation the tendons were deepfreeze to $-20^{\circ} \mathrm{C}$ and during the sterilization were on dry ice. The gamma irradiation caused a deterioration in failure load, and Young's modulus of elasticity [29, 41, 43, 45] Aguila et al. [29] used 15-25 kGy for peroneus longus and peroneus brevis, Deyne and Haut [41] used $20 \mathrm{kGy}$ for patellar tendons, Ren et al. [43] used $25 \mathrm{kGy}$ for flexor digitorum superficialis, and Rasmussen et al. [45] used $40 \mathrm{kGy}$ for the patellar tendon. Greaves et al. [38] compared three age groups ("young", "middle", "old"). Deterioration can be observed in the "middle" age group and the "old" age group. There are values of failure load, and Young's modulus of elasticity, no noticeable change in the "young" age group [38].

\section{Supercritical carbon dioxide (SCCO2)}

Supercritical carbon dioxide is an alternative sterilization method ([28], Table 4). We found one relevant article on this method [28], but the article compares several sterilization methods. The allografts were secured in their casing and placed in a chamber with heated and pressurized $\mathrm{CO}_{2}$, which forms a solvent that sterilizes the allograft. Baldini et al. [28] compared the SCCO2 method with gamma irradiation in anterior and posterior tibialis. Based on the measurements, the $\mathrm{SCCO} 2$ treated grafts show higher values of failure load and Young's modulus of elasticity than the gamma irradiation group ([28], Table 4).

\section{Ethylene oxide}

We found one relevant article on this method [51]. Bechtold et al. [51] used ethylene oxide for sterilization ([51], Table 5), and the study presented two types of freezing as a control group. The grafts are assigned to freeze-drying and sterilization. The tendon is exposed to $12 \%$ ethylene oxide gas at $32{ }^{\circ} \mathrm{C}$ for $15 \mathrm{~h}$, with a relative humidity of approximately $80 \%$ before being freezedried. This alternative procedure does not improve the failure load and Young's modulus of elasticity of the tendons ([51], Table 5).

\section{BioCleanse}

Following the BioCleanse protocol, all tendons were closed in a chamber and were exposed to a solvent at differing pressures and vacuum cycles $([8,32-34,52]$; Table 6). The treatment group was exposed to the chemical solutions for twice as long as the standard time of exposure. This was designed to portray the worst outcome for degrading the structural and mechanical characteristics of the donor material [52]. Based on the results, the failure load and Young's modulus of elasticity showed weaker results than gamma irradiation group ([8, 32-34, 52]; Table 6).

\section{Electron beam (E-beam)}

The sterilization method did not differ much from the traditional gamma irradiation method ([31, 48, 49, 53, 54]; Table 7). The tendon grafts were encased in a specially created Styrofoam box, packed with dry ice to preserve the approximate temperature of $-40^{\circ} \mathrm{C}$ to $-50^{\circ} \mathrm{C}$ throughout the complete irradiation process. Stronger mechanical properties are achieved by the E-beam method ([31, 48, 49, 53, 54]; Table 7) compared to the method with gamma irradiation, but there were no differences.

\section{Peracetic acid-ethanol in combination with low-dose gamma irradiation (PE- $R$ )}

This hybrid method consists of chemical sterilization and gamma radiation ([35]; Table 8). We found one

Table 6 Average result of failure load and Young's modulus of elasticity of sterilized tendons with BioCleanse [8, 32-34, 52]

\begin{tabular}{lllll}
\hline Type of tendon & Pieces & Failure load(Standard Deviation) $[\mathbf{N}]$ & $\begin{array}{l}\text { Young's modulus of elasticity (Standard Deviation) } \\
{[\mathrm{MPa}]}\end{array}$ & Authors \\
\hline Achilles & 10 & $2472(701)$ & $154.06(104.54)$ & Conrad et al. \\
Tibialis anterior & 12 & $1559(176)$ & $484.2(99.1)$ & Colaco et al. \\
Tibialis anterior & 12 & $1651.6(377.4)$ & $19.7(5.4)$ & Schimizzi et al. \\
\hline
\end{tabular}


Table 7 Average result of failure load and Young's modulus of elasticity of sterilized tendons with Electron Beam [31, 48, 49, 53, 54]

\begin{tabular}{|c|c|c|c|c|c|}
\hline Type of tendon & Irradiation dose & Pieces & $\begin{array}{l}\text { Failure load(Standard } \\
\text { Deviation) }[\mathrm{N}]\end{array}$ & $\begin{array}{l}\text { Young's modulus of elasticity (Standard } \\
\text { Deviation) [MPa] }\end{array}$ & Authors \\
\hline Tibialis tendon & 9.2-12.2 kGy & 10 & 876.38 (310.73) & $206.71(88.87)$ & \multirow{2}{*}{$\begin{array}{l}\text { Elenes } \\
\text { et al. }\end{array}$} \\
\hline Tibialis tendon & 17.1-21.0 kGy & 10 & $660.24(312.12)$ & $152.64(75.10)$ & \\
\hline $\begin{array}{l}\text { Human flexor digitorum } \\
\text { superficialis }\end{array}$ & 50 kGy & 10 & $282.3(53.0)$ & $291.6(50.8)$ & \multirow[t]{3}{*}{ Wei et al. } \\
\hline $\begin{array}{l}\text { Human flexor digitorum } \\
\text { superficialis }\end{array}$ & $50 \mathrm{kGy}$, fractionation & 10 & $360.9(49.3)$ & $354.3(49.1)$ & \\
\hline $\begin{array}{l}\text { Human flexor digitorum } \\
\text { superficialis }\end{array}$ & $\begin{array}{l}50 \mathrm{kGy} \text {, fractionation + } \\
\text { ascorbate }\end{array}$ & 10 & $390,6(42.1)$ & $390.4(50.6)$ & \\
\hline $\begin{array}{l}\text { Bone - patellar tendon - } \\
\text { bone }\end{array}$ & 34 kGy & 11 & $1024(204)$ & - & \multirow[t]{2}{*}{$\begin{array}{l}\text { Hoburg } \\
\text { et al. }\end{array}$} \\
\hline $\begin{array}{l}\text { Bone - patellar tendon - } \\
\text { bone }\end{array}$ & $34 \mathrm{kGy}$, fractionated & 11 & $1327(305)$ & - & \\
\hline $\begin{array}{l}\text { Bone - patellar tendon - } \\
\text { bone }\end{array}$ & 25 kGy & 10 & 1177 (512) & - & \multirow[t]{2}{*}{$\begin{array}{l}\text { Hoburg } \\
\text { et al. }\end{array}$} \\
\hline $\begin{array}{l}\text { Bone - patellar tendon - } \\
\text { bone }\end{array}$ & 34 kGy & 10 & $1139(445)$ & - & \\
\hline
\end{tabular}

relevant article on this method [35], but the article compares several sterilization methods. The PAA/ethanol (PE) solution was prepared using distilled water and absolute ethanol. It consisted of $0.2 \%$ PAA and $24 \%$ ethanol. Tendons were submerged in the PE solution for 30 min and later washed with a saline solution until the concentration of PAA was lower than $1 \mathrm{ppm}$. The refined human flexor tendons were then closed and subjected to gamma irradiation at an average dose of 15 kGy. The sterilized muscles were stowed at $-80^{\circ} \mathrm{C}$ [35], and they showed stronger mechanical results than the control group. This hybrid procedure has not been compared with other sterilization methods ([35]; Table 8).

\section{Hydrogen peroxide}

We found only one relevant article on this method [55], but the article summarized the effect of hydrogen peroxide on several tendons. This chemical process requires that $3 \%$ hydrogen peroxide be added to the solution ([55]; Table 9). The tissues should be left in the solution for $5 \mathrm{~min}$ in room temperature and the tendons were stored at $-80^{\circ} \mathrm{C}$. This is the time needed to kill the bacteria. Based on the results of the study, there is no change in the mechanical properties of treated and untreated tendons. Gardner et al. did not compare this method with other sterilization methods. This is sufficient to kill bacteria but not enough to kill viruses ([55]; Table 9).

\section{Chlorhexidine}

In this chemical process, the experimental group is immersed in a $4 \%$ chlorhexidine gluconate solution for $30 \mathrm{~min}$, while the control group was kept moist in saline gauze. The results of patellar tendons were not compared with other sterilization procedures [36]. The experimental group had stronger mechanical properties than the control group, this property does not result in tissue alterations that adversely affect its clinical application ([36]; Table 10). We found one relevant article on this method, but the article compares several sterilization methods.

\section{Discussion}

The two factors that can affect the mechanical properties of a tendon are the type of tendon and the sterilization methods. Tendon grafts show to be promising for transplants. It is important to sterilize the tendons to ensure no bacteria is transmitted that could cause infections. We reviewed peroneus longus, peroneus brevis, tibialis anterior, tibialis posterior, patellar tendon, human flexor digitorum superficial, Achilles, bone-patellar tendon-bone, semitendinosus, semitendinosus + gracilis, fascia lata types of tendon and gamma irradiation, SCCO2, ethylene oxide, BioCleanse, E-Beam, PE-R, hydrogen peroxide, chlorhexidine sterilization methods.

Gamma radiation is the most common method of sterilization (Table 3). The 14.8-28.5 kGy (1.48-2.85

Table 8 Average result of failure load and Young's modulus of elasticity of sterilized tendons with PE-R [35]

\begin{tabular}{lcccc}
\hline Type of tendon & Pieces & Failure load(Standard Deviation) $[\mathrm{N}]$ & $\begin{array}{l}\text { Young's modulus of elasticity (Standard Deviation) } \\
{[\mathrm{MPa}]}\end{array}$ & Authors \\
\hline Human flexor tendons & - & $306.96(61.52)$ & $235.78(96.13)$ & Zhou et al. \\
\hline
\end{tabular}


Table 9 Average result of failure load and Young's modulus of elasticity of sterilized tendons with Hydrogen peroxide [55]

\begin{tabular}{llll}
\hline Type of tendon & Pieces & $\begin{array}{l}\text { Ultimate tensile strength (Standard Deviation) } \\
{[\mathrm{MPa}]}\end{array}$ & $\begin{array}{l}\text { Young's modulus of elasticity (Standard } \\
\text { Deviation) } \\
{[\mathrm{MPa}]}\end{array}$ \\
\hline Tibialis posterior & 5 & $2366(447)$ & - \\
Tibialis anterior & 2 & $2308(806)$ & - \\
$\begin{array}{l}\text { Extensor digitorum } \\
\text { longus }\end{array}$ & 6 & $1574(116)$ & - \\
$\begin{array}{l}\text { Extensor halluces logus } \\
\text { Flexor digitorum }\end{array}$ & 5 & $588(16)$ & - \\
longus & 1 & 1087 & - \\
Flexor halluces logus & 3 & $1210(155)$ &
\end{tabular}

Mrad) radiation proved best because this radiation dose killed bacteria, according to Document ISO 11137 [56], $15 \mathrm{kGy}$ can sterilize tendon if bioburden is less than 1,5 $\mathrm{cfu} / \mathrm{item}$ and $25 \mathrm{kGy}$ can sterilize tendon if bioburden not more than $1000 \mathrm{cfu} /$ item. Many tissue banks have developed clean rooms whereby the processing of tendon is carried out under aseptic environment. The tissues have very low microorganism count or bioburden and mostly no bacterial count at all. As radiation doses can be selected and validated based bioburden in the tissue, there is a tendency that many tissue banks would want to irradiate soft tissues at doses lower than $25 \mathrm{kGy}$ (the most commonly used radiation dose) therefore will avoid effects of radiation on mechanical properties. It also kept the failure load (e.g., failure load of Achilles sterilized at $18-24 \mathrm{kGy}$ is $3572.54 \mathrm{~N}$ vs. failure load of Achilles sterilized at $38-46 \mathrm{kGy}$ is $392.01 \mathrm{~N}$, tibialis anterior sterilized at $18-24 \mathrm{kGy}$ : $3107.76 \mathrm{~N}$, failure load of tibialis anterior sterilized at 38-46 kGy: $2678.96 \mathrm{~N}$ [45, 46]. Comparing with section 3.1.1 (non-sterilized tendon), the results showed that failure load improved (Achilles: $3032 \mathrm{~N}$, tibialis anterior: $2427.3 \mathrm{~N}$ ). It can be observed that the failure load's tendency of quadriceps was different $(18-24 \mathrm{kGy}: \quad 3184.32 \mathrm{~N}, \quad 38-46 \mathrm{kGy}$ : $3464.35 \mathrm{~N})$. At $38-46 \mathrm{kGy}(3.8-4.6 \mathrm{Mrad})$, the radiation killed viruses as well, but the biomechanical properties deteriorate (Tables 2 and 3) [29, 37-47];

The effectiveness of sterilization depends on the temperature and the dose. Samples should be cooled to at least $-70^{\circ} \mathrm{C}$ prior to sterilization, and using dry ice or liquid nitrogen, samples should also be cooled during gamma irradiation, as heat is generated during the procedure, which can cause tendons to melt and decompose, leading to tissue damage. At high doses $>25 \mathrm{kGy}$, tissue damage and poorer mechanical properties are also observed, therefore virucidal sterilization is not recommended. Viruses can be detected during screening tests and infected samples can be excluded from further use. The supercritical carbon dioxide (SCCO2) sterilization method has been discussed only by Baldini et al. [28]. Baldini et al. discussed anterior or posterior tibial tendon treated with $\mathrm{SCCO} 2$. Based on the results, there was a negligible improvement in the failure load and Young's modulus of elasticity of the tendons (non-sterilized: $2427.3 \mathrm{~N}, \quad 75.4 \mathrm{MPa}$ vs. SCCO2: $2450.3 \mathrm{~N}, 91.9 \mathrm{MPa}$ ) ([28]; Tables 2 and 3). The origin of samples and measurement methods are different; the result could not be compared to the results of different sterilization methods. Therefore, we cannot accurately conclude.

The Ethylene oxide procedure does not yield higher mechanical properties than other methods ([51]; Table 5). Tendons sterilized with this method generate connective tissue growth. During this tissue growth, cancerous cells can develop. Bechtold et al. [48] examined the patellar tendon and its Young's modulus of elasticity. After sterilization, Young's modulus of the tendon deteriorated slightly (non-sterilized: $158.0 \mathrm{MPa}$, sterilized: 143.0 MPa). This sterilization method is also not comparable to other sterilization methods, but the method impaired Young's modulus of the patellar tendon [51].

The BioCleanse wash poses the same issues as the hydrogen peroxide and chlorhexidine method ([32-34, 52]; Table 6). Since this is a wash, only the outside of the tendon is sterilized. Dangerous bacteria might still be found in the tendon. The BioCleanse solution is not as effective as gamma irradiation. The sterilization method is addressed in three studies (Table 6). Conrad et al. [8] examined the failure load and Young's modulus of the Achilles after different sterilization. BioCleanse and gamma irradiation sterilization methods are

Table 10 Average result of failure load and Young's modulus of elasticity of sterilized tendons with Chlorhexidine [36]

\begin{tabular}{llcll}
\hline Type of tendon & Pieces & $\begin{array}{l}\text { Failure load(Standard Deviation } \\
{[\mathrm{N}]}\end{array}$ & Young modulus of elasticity [MPa] & Authors \\
\cline { 2 - 4 } & 8 & $2219(808.1)$ & - & Sobel et al. \\
\hline Patellar tendon & 8 & &
\end{tabular}


investigated, and compared the result of mechanical properties of non-sterilized tendon. In the case of failure load, BioCleanse shows lower results than non-sterilized, but even weaker are the results of the gamma irradiation sterilization method (non-sterilized: $3032 \mathrm{~N}$, BioCleanse: $2472 \mathrm{~N}$, gamma irradiation: $1972 \mathrm{~N}$ ). The values of the modulus of elasticity showed a similar tendency (292.04-154.06-129.48 MPa) [8]. Colaco et al. [32] and Schimizzi et al. [33], the tibialis anterior was examined. Colaco et al. [32] compared different BioCleanse mixtures. However, no comparison was made with other sterilization methods. Schimizzi et al. [33] analyzed the effect of sterilization by BioClense and gamma irradiation on the mechanical properties of tibialis anterior. The results were compared to mechanical properties of non sterilized tendon.. Based on the results, BioCleanse did not achieve lower results (failure load and Young's modulus) compared to the other two groups (non-sterilized: $1665 \mathrm{~N}$ and $19.9 \mathrm{MPa}$, gamma-irradiated: $1671.9 \mathrm{~N}$ and 22.6 MPa, BioCleanse: $1651.6 \mathrm{~N}$ and 19.7 MPa) [33].

The effect of sterilization by Electron Beam (E-beam) was analyzed in three articles ([31, 48, 53], Table 7). Elenes et al. [48] compared failure load of the tibialis anterior with non-sterilized, gamma irradiation, and Ebeam sterilization methods. It uses two types of E-beam doses, one low (9.2-12.2 kGy) and one high (17.1-21.0 $\mathrm{kGy}$ ). Based on the maximum load results [53], the lowdose E-beam performed significantly higher compared to the other three categories (non-sterilized: $606.73 \mathrm{~N}$, Ebeam low: $876.38 \mathrm{~N}$, E-beam high: $660.24 \mathrm{~N}$, gamma: $597.09 \mathrm{~N}$ ). In comparison to the values of modulus of elasticity, it can be observed that the values decrease for all three sterilization methods compared to nonsterilized ones. Of the three sterilization methods, the smallest deterioration is shown by E-beam low (nonsterilized: 213.13 MPa, E-beam low: 206.71 MPa, E-beam high: $152.64 \mathrm{MPa}$, gamma: $179.02 \mathrm{MPa}$ ) [48]. Wei et al. [31] compared three types of E-beam doses to the nonsterilized group. Based on the results, all three doses of E-beam performed lower than the non-sterilized human flexor digitorum superficialis (fresh: $402.5 \mathrm{~N}$ and 400.5 $\mathrm{MPa}, 50 \mathrm{kGy}: 282.3 \mathrm{~N}$ and $291.6 \mathrm{MPa}, 50 \mathrm{kGy}$ (Fr.): $360.9 \mathrm{~N}$ and $354.3 \mathrm{MPa}, 50 \mathrm{kGy}$ (Fr. + As.): $390.6 \mathrm{~N}$ and 390.4 MPa) [31]. Hoburg et al. [49] examined the Ebeam in the most recent of his studies. Bone-patellar tendon-bone treated with two doses of E-beam radiation (25 and 34 kGy) was compared with two different doses of gamma radiation (25 and $34 \mathrm{kGy}$ ) and non-sterilized. Based on the results, all four sterilizations significantly decreased the maximum force values; however, the values of E-beam are stronger than the values of the same dose of gamma radiation (non-sterilized: $1741 \mathrm{~N}$, gamma 25 kGy: $1009 \mathrm{~N}$, E-beam 25 kGy: $1177 \mathrm{~N}$, gamma 34 kGy: $1073 \mathrm{~N}$, E-beam 34 kGy: 1139 N) [49]. Zhou et al. [35] examined human flexor tendon sterilized with Peracetic acid - ethanol in combination with low-dose gamma irradiation (PE-R). The results showed a lower failure load compared to the non-sterilized tendon (nonsterilized: $360.01 \mathrm{~N}$ and $221.55 \mathrm{MPa}, \mathrm{PE}-\mathrm{R}: 306.96 \mathrm{~N}$, and $235.78 \mathrm{MPa}$ ). PE- $\mathrm{R}$ is a hybrid method consisting of immersing the tendon in a chemical solution and then using gamma irradiation. This method yielded a lower failure load than the Electron beam sterilization and gamma sterilization [35].

The hydrogen peroxide method is just a wash; the inside of the tendon is not properly sterilized, which can lead to infections. Gardner et al. [55] examined the effect of hydrogen peroxide on several different types of tendons. The ultimate tensile strength was not compared to other sterilization methods or non-sterilized tendons (Table 9). Comparing the results of the ultimate tensile strength of previous studies with the results, hydrogen peroxide is not a suitable method for sterilizing tendons [55].

The Chlorhexidine chemical solution is also a wash, the same as the hydrogen peroxide method [36]. While it does pose higher results of failure load for the tendon, the inside of the tendon is not properly sterilized. According to the method of Sobel et al. [36] showed that the value of the failure load increases as a result of sterilization (non-sterilized: $1876 \mathrm{~N}$, Chlorhexidine: 2219 N) (Table 10).

Based on a systematic literature review, it can be established that the most common method of sterilization is gamma radiation. However, after comparing the different literature, it is established that mechanical properties are improved, compared to non-sterilized tendons, with the E-beam sterilization method. The method is not widespread, due to the lack of laboratories and instruments suitable for conducting this treatment. The procedure using Chlorhexidine has yielded similar results to the E-beam. Only a few studies are available on the subject, so further research is needed. Gamma and electron sterilization service is offered by irradiation facilities and no lab-scale instrument for electron beam is available. Even self-shielded Gammacell with small irradiation compartment is extremely expensive and very costly to maintain and need nuclear personnel to validate. The existing practice is tissue banks will send packages of tissues to certified gamma and electron beam facilities that offer sterilization service.

\section{Limitation}

This review analyzed and classified multiple existing sterilization methods used in determining the biomechanical properties of tendons. Since this review looked at different techniques, a meta-analysis could not be performed. Limitations can also surface because only three major scientific databases were utilized in the search for 
papers. Because of the full range of this research, it only provides an overview of multiple sterilization processes. This review is not meant to be exhaustive but to provide manuscript limitation examples. It does not discuss the advancement of any single process. Two studies analyzed the effect of different sterilization methods on the mechanical properties of same tendon $[8,33]$. The most research The results of different studies for the same tendon cannot be numerically compared because sterilization method (chemical, radiation), storage and handling are different. In the future, the effect of different sterilization method should be analyzed on the mechanical properties on the same tendon.

\section{Conclusion}

The purpose of this literature review was to systematically evaluate existing literature to compare the biomechanical effects of different sterilization methods on commonly used tendon allografts. The mechanical properties of tendons that were determined included failure load and Young's modulus of elasticity.

Based on a systematic literature review, we recommend freezing and gamma irradiation or electron beam at $14.8-28.5 \mathrm{kGy}$. This is especially useful for new bone bankers who prefer to supply non-processed frozen bones that are sterilized by radiation. These methods are effective at keeping or improving the mechanical properties, while fully sterilizing the inside and the outside of the tendon. Other sterilization method (ethylene oxide, supercritical carbon dioxide (SCCO2), BioCleanse) deteriorated the mechanical properties. These methods are not recommended.

\section{Abbreviations}

ACL: Anterior cruciate ligament; SCCO2: supercritical carbon dioxide; Ebeam: Electron Beam; PE-R: Peracetic acid-ethanol in combination with lowdose gamma irradiation

\section{Supplementary Information}

The online version contains supplementary material available at https://doi. org/10.1186/s12891-021-04296-4.

Additional file1: Figure S1. PRISMA flow diagram of the systemic review process.

\section{Acknowledgments}

This research was supported by the National Research, Development, and Innovation Office (OTKA K 116189).

The research reported in this paper and carried out at the Budapest University of Technology and Economics was supported by the "TKP2020, Institutional Excellence Program" of the National Research Development and Innovation Office in the field of Biotechnology (BME IE-BIO TKP2020).

\section{Authors' contributions}

DF, BK analyzed and interpreted the patient data regarding the hematological disease and the transplant. DF, RK performed the histological examination of the kidney and was a major contributor in writing the manuscript. All authors read and approved the final manuscript.

\section{Funding}

The research reported in this paper was supported by the Higher Education Excellence Program of the Ministry of Human Capacities within the Biotechnology research area of Budapest University of Technology and Economics (BME FIKP-BIO). This research was supported by the National Research, Development and Innovation Office (OTKA K 116189).

The research reported in this paper has been supported by the National Research, Development and Innovation Fund (TUDFO/51757/2019-ITM, Thematic Excellence Program).

\section{Availability of data and materials}

The data that support the findings of this study are available from authors of not open access journals but restrictions apply to the availability of these data, which were used under license for the current study, and so are not publicly available. Data are however available from Denes Farago upon reasonable request and with permission of authors of not open access journals. All data generated or analysed during this study are included in this published review.

\section{Declarations}

Ethics approval and consent to participate

Not applicable.

\section{Consent for publication}

Not applicable.

\section{Competing interests}

The authors declare that they have no competing interests.

\section{Author details}

${ }^{1}$ Cooperation Research Center for Biomechanics, Faculty of Mechanical Engineering, Budapest University of Technology and Economics, Budapest, Hungary. ${ }^{2}$ Department of Mechatronics, Optics and Mechanical Engineering Informatics, Faculty of Mechanical Engineering, Budapest University of Technology and Economics, Budapest, Hungary. ${ }^{3}$ Department of Biomedical Engineering, SUNY University at Buffalo, Buffalo, USA.

Received: 3 February 2021 Accepted: 23 April 2021

Published online: 30 April 2021

\section{References}

1. Indelicato PA, Linton RC, Huegel M. The results of fresh-frozen patellar tendon allografts for chronic anterior cruciate ligament deficiency of the knee. Am J Sports Med. 1992;20(2):118-21. https://doi.org/10.1177/036354 659202000204.

2. Zoltan DJ, Reinecke C, Indelicato PA. Synthetic and allograft anterior cruciate ligament reconstruction. Clin Sports Med. 1988;7(4):773-84. https:// doi.org/10.1016/S0278-5919(20)30884-X

3. Wainer RA, Clarke TJ, Poehling GG. Arthroscopic reconstruction of the anterior cruciate ligament using allograft tendon. Arthrosc J Arthrosc Relat Surg. 1988;4(3):199-205. https://doi.org/10.1016/S0749-8063(88)80027-6.

4. Prodromos C, Joyce B, Shi K. A meta-analysis of stability of autografts compared to allografts after anterior cruciate ligament reconstruction. Knee Surgery, Sport. Traumatol. Arthrosc. 2007;15(7):851-6. https://doi.org/10.1 007/s00167-007-0328-6.

5. Nikolaou PK, Seaber AV, Glisson RR, Ribbeck BM, Bassett FH. Anterior cruciate ligament allograft transplantation. Am J Sports Med. 1986;14(5): 348-60. https://doi.org/10.1177/036354658601400502.

6. Shino K, Kimura T, Hirose H, Inoue M, Ono K. Reconstruction of the anterior cruciate ligament by allogeneic tendon graft. An operation for chronic ligamentous insufficiency. J Bone Joint Surg Br. 1986;68(5):739-46.

7. Noyes FR, Barber SD, Mangine RE. Bone-patellar ligament-bone and fascia lata allografts for reconstruction of the anterior cruciate ligament. J Bone Joint Surg Am. 1990;72(8):1125-36. https://doi.org/10.2106/00004623-199072 080-00002.

8. Conrad BP, Rappé M, Horodyski M, Farmer KW, Indelicato PA. The effect of sterilization on mechanical properties of soft tissue allografts. Cell Tissue Bank. 2013;14(3):359-66. https://doi.org/10.1007/s10561-012-9340-2. 
9. Chang SKY, Egami DK, Shaieb MD, Kan DM, Richardson AB. Anterior cruciate ligament reconstruction: allograft versus autograft. Arthrosc. J. Arthrosc. Relat. Surg. 2003;19(5):453-62. https://doi.org/10.1053/jars.2003.50103.

10. Harner CD, Olson E, Irrgang JJ, Silverstein S, Fu FH, Silbey M. Allograft versus autograft anterior cruciate ligament reconstruction: 3- to 5-year outcome. Clin Orthop Relat. Res. 1996;(324):134-44. https://doi.org/10.1097/00003 086-199603000-00016.

11. Pacifici M. Retinoid roles and action in skeletal development and growth provide the rationale for an ongoing heterotopic ossification prevention trial. Bone. 2018;109:267-75.

12. Bottoni CR, Smith EL, Shaha J, Shaha SS, Raybin SG, Tokish JM, et al. Autograft versus allograft anterior cruciate ligament reconstruction. Am J Sports Med. 2015;43(10):2501-9. https://doi.org/10.1177/0363546515596406.

13. Kartus J, Movin T, Karlsson J. Donor-site morbidity and anterior knee problems after anterior cruciate ligament reconstruction using autografts. Arthrosc. J. Arthrosc. Relat. Surg. 2001;17(9):971-80. https://doi.org/10.1053/ jars.2001.28979.

14. Wee J, Lee KT. Graft infection following arthroscopic anterior cruciate ligament reconstruction: a report of four cases. J Orthop Surg. 2014;22(1): 111-7. https://doi.org/10.1177/230949901402200128.

15. Crawford C, Kainer M, Jernigan D, Banerjee S, Friedman C, Ahmed F, et al. Investigation of postoperative allograft-associated infections in patients who underwent musculoskeletal allograft implantation. Clin Infect Dis. 2005;41(2): 195-200. https://doi.org/10.1086/430911

16. Genuario JW, Faucett SC, Boublik M, Schlegel TF. A cost-effectiveness analysis comparing 3 anterior cruciate ligament graft types. Am J Sports Med. 2012;40(2):307-14. https://doi.org/10.1177/0363546511426088.

17. Schmidt T, Grabau D, Grotewohl JH, Gohs U, Pruß A, Smith M, et al. Does sterilization with fractionated electron beam irradiation prevent ACL tendon allograft from tissue damage? Knee Surgery, Sport. Traumatol. Arthrosc. 2017;25(2):584-94. https://doi.org/10.1007/s00167-016-4240-9.

18. Tang J, Zeng F, Savage H, Ho PP, Alfano RR. Laser irradiative tissue probed in situ by collagen 380-nm fluorescence imaging. Lasers Surg Med. 2000; 27(2):158-64. https://doi.org/10.1002/1096-9101(2000)27:2<158::AID-LSM7>3. $0 . \mathrm{CO} ; 2-1$.

19. Tejwani SG, Chen J, Funahashi $\pi$, Love R, Maletis GB. Revision risk after allograft anterior cruciate ligament reconstruction. Am J Sports Med. 2015; 43(11):2696-705. https://doi.org/10.1177/0363546515589168.

20. Mroz TE, Joyce MJ, Steinmetz MP, Lieberman IH, Wang JC. Musculoskeletal allograft risks and recalls in the United States. J Am Acad Orthop Surg. 2008; 16(10):559-65. https://doi.org/10.5435/00124635-200810000-00001.

21. Park SS-H, Dwyer T, Congiusta F, Whelan DB, Theodoropoulos J. Analysis of irradiation on the clinical effectiveness of Allogenic tissue when used for primary anterior cruciate ligament reconstruction. Am J Sports Med. 2015: 43(1):226-35. https://doi.org/10.1177/0363546513518004.

22. Carlson ER, Marx RE, Buck BE. The potential for HIV transmission through allogeneic bone. A review of risks and safety. Oral Surg Oral Med Oral Pathol Oral Radiol Endod. 1995;80(1):17-23. https://doi.org/10.1016/S1079-21 04(95)80010-7.

23. Kainer MA, Linden JV, Whaley DN, Holmes HT, Jarvis WR, Jernigan DB, et al. Clostridium infections associated with musculoskeletal-tissue allografts. N Engl J Med. 2004;350(25):2564-71. https://doi.org/10.1056/NEJMoa023222.

24. Buck BE, Malinin TI, Brown MD. Bone transplantation and human immunodeficiency virus. An estimate of risk of acquired immunodeficiency syndrome (AIDS). Clin. Orthop. Relat. Res. 1989;(240):129-36.

25. Centers for Disease Control and Prevention (CDC). Septic arthritis following anterior cruciate ligament reconstruction using tendon allografts--Florida and Louisiana, 2000. MMWR Morb Mortal Wkly Rep. 2001;50(48):1081-3.

26. AATB Standards of Tissue Banking 14th edition. https:/www.aatb.org/standards. Accessed 25 Mar 2021.

27. Liberati A, et al. The PRISMA Statement for Reporting Systematic Reviews and Meta-Analyses of Studies That Evaluate Health Care Interventions: Explanation and Elaboration. PLoS Med. 2009;6(7):e1000100

28. Baldini T, Caperton K, Hawkins M, McCarty E. Effect of a novel sterilization method on biomechanical properties of soft tissue allografts. Knee Surgery, Sport Traumatol Arthrosc. 2016;24(12):3971-5. https://doi.org/10.1007/s001 67-014-3221-0.

29. Aguila CM, Delcroix GJ-R, Kaimrajh DN, Milne EL, Temple HT, Latta LL. Effects of gamma irradiation on the biomechanical properties of peroneus tendons. Open Access J Sport Med. 2016;7:123-7. https://doi.org/10.2147/ OAJSM.S109156
30. Suhodolčan L, Brojan M, Kosel F, Drobnič M, Alibegović A, Brecelj J. Cryopreservation with glycerol improves the in vitro biomechanical characteristics of human patellar tendon allografts. Knee Surgery, Sport. Traumatol. Arthrosc. 2013;21(5):1218-25. https://doi.org/10.1007/s00167012-1954-1.

31. Wei W, Liu Y, Yang X, Tian S, Liu C, Zhang Y, et al. Fractionation of 50kGy electron beam irradiation: effects on biomechanics of human flexor digitorum superficialis tendons treated with ascorbate. J Biomech. 2013; 46(4):658-61. https://doi.org/10.1016/j.jbiomech.2012.11.049.

32. Colaço HB, Lord BR, Back DL, Davies AJ, Amis AA, Ajuied A. Biomechanical properties of bovine tendon xenografts treated with a modern processing method. J Biomech. 2017;53:144-7. https://doi.org/10.1016/j.jbiomech.2017. 01.011 .

33. Schimizzi A, Wedemeyer M, Odell T, Thomas W, Mahar AT, Pedowitz R. Effects of a novel sterilization process on soft tissue mechanical properties for anterior cruciate ligament allografts. Am J Sports Med. 2007;35(4):612-6. https://doi.org/10.1177/0363546506295083.

34. Jones DB, Huddleston PM, Zobitz ME, Stuart MJ. Mechanical properties of patellar tendon allografts subjected to chemical sterilization. Arthrosc - J Arthrosc Relat Surg. 2007;23(4):400-4. https://doi.org/10.1016/j.arthro.2 006.11.031.

35. Zhou M, Zhang N, Liu X, Li Y, Zhang Y, Wang X, et al. Tendon allograft sterilized by peracetic acid/ethanol combined with gamma irradiation. J Orthop Sci. 2014;19(4):627-36. https://doi.org/10.1007/s00776-014-0556-9.

36. Sobel AD, Hohman D, Jones J, Bisson LJ. Chlorhexidine gluconate cleansing has no effect on the structural properties of human patellar tendon allografts. Arthrosc. - J. Arthrosc. Relat. Surg. 2012;28(12):1862-6. https://doi. org/10.1016/j.arthro.2012.05.888.

37. Balsly CR, Cotter AT, Williams LA, Gaskins BD, Moore MA, Wolfinbarger L. Effect of low dose and moderate dose gamma irradiation on the mechanical properties of bone and soft tissue allografts. Cell Tissue Bank. 2008;9(4):289-98. https://doi.org/10.1007/s10561-008-9069-0.

38. Greaves LL, Hecker AT, Brown CH. The effect of donor age and low-dose gamma irradiation on the initial biomechanical properties of human tibialis tendon allografts. Am J Sports Med. 2008;36(7):1358-66. https://doi.org/1 $0.1177 / 0363546508314394$

39. Curran AR, Adams DJ, Gill JL, Steiner ME, Scheller AD. The biomechanical effects of low-dose irradiation on bone-patellar tendon-bone allografts. Am J Sports Med. 2004;32(5):1131-5. https://doi.org/10.1177/0363546503260060.

40. Gut G, Marowska J, Jastrzebska A, Olender E, Kamiński A. Structural mechanical properties of radiation-sterilized human bone-tendon-bone grafts preserved by different methods. Cell Tissue Bank. 2016;17(2):277-87. https://doi.org/10.1007/s10561-015-9538-1.

41. De Deyne P, Haut RC. Some effects of gamma irradiation on patellar tendon allografts. Connect Tissue Res. 1991;27(1):51-62. https://doi.org/10.3109/03 008209109006994

42. Weber $A E$, et al. How variable are Achilles allografts used for anterior cruciate ligament reconstruction? A biomechanical study. Am J Sports Med. 2018:1-7. https://doi.org/10.1177/0363546518768780.

43. Ren D, Sun K, Tian S, Yang X, Zhang C, Wang W, et al. Effects of gamma irradiation and repetitive freeze-thaw cycles on the biomechanical properties of human flexor digitorum superficialis tendons. J Biomech. 2012; 45(2):252-6. https://doi.org/10.1016/j.jbiomech.2011.10.035.

44. Dziedzic-Goclawska A, Kaminski A, Uhrynowska-Tyszkiewicz I, Stachowicz W. Irradiation as a safety procedure in tissue banking. Cell Tissue Bank. 2005; 6(3):201-19. https://doi.org/10.1007/s10561-005-0338-x.

45. Rasmussen TJ, Feder SM, Butler DL, Noyes FR. The effects of 4 Mrad of gamma irradiation on the initial mechanical properties of bone-patellar tendon-bone grafts. Arthroscopy. 1994;10(2):188-97. https://doi.org/10.1016/ S0749-8063(05)80092-1.

46. Hangody G, Szebényi G, Abonyi B, Kiss R, Hangody L. Does a different dose of gamma irradiation have the same effect on five different types of tendon allografts? - a biomechanical study; 2017. p. 357-65.

47. Azar FM. Tissue processing: role of secondary sterilization techniques. Clin Sports Med. 2009;28(2):191-201. https://doi.org/10.1016/j.csm.2008.10.003.

48. Elenes EY, Hunter SA. Soft-tissue allografts terminally sterilized with an electron beam are biomechanically equivalent to aseptic, non-sterilized tendons. J Bone Jt Surg - Am Vol. 2014;96(16):1321-6. https://doi.org/10.2106/JBJS.L.00841.

49. Hoburg A, Keshlaf S, Schmidt T, Smith M, Gohs U, Perka C, et al. High-dose electron beam sterilization of soft-tissue grafts maintains significantly improved biomechanical properties compared to standard gamma 
treatment. Cell Tissue Bank. 2015;16(2):219-26. https://doi.org/10.1007/s1 0561-014-9461-X.

50. Schmidt T, Hoburg A, Broziat C, Smith MD, Gohs U, Pruss A, et al. Sterilization with electron beam irradiation influences the biomechanical properties and the early remodeling of tendon allografts for reconstruction of the anterior cruciate ligament (ACL). Cell Tissue Bank. 2012;13(3):387-400. https://doi.org/10.1007/s10561-011-9289-6.

51. Bechtold JE, Eastlund DT, Butts MK, Lagerborg DF, Kyle RF. The effects of freeze-drying and ethylene oxide sterilization on the mechanical properties of human patellar tendon. Am J Sports Med. 1994;22(4):562-6. https://doi. org/10.1177/036354659402200421.

52. Mroz TE, Lin EL, Summit MC, Bianchi JR, Keesling JE Jr, Roberts M, et al. Biomechanical analysis of allograft bone treated with a novel tissue sterilization process. Spine J. 2006;6(1):34-9. https://doi.org/10.1016/j. spinee.2005.10.007.

53. Hoburg AT, Keshlaf S, Schmidt T, Smith M, Gohs U, Perka C, et al. Effect of Electron beam irradiation on biomechanical properties of patellar tendon allografts in anterior cruciate ligament reconstruction. Am J Sports Med. 2010;38(6):1134-40. https://doi.org/10.1177/0363546509361161.

54. Hoburg A, Keshlaf S, Schmidt T, Smith M, Gohs U, Perka C, et al. Fractionation of high-dose electron beam irradiation of BPTB grafts provides significantly improved viscoelastic and structural properties compared to standard gamma irradiation. Knee Surgery, Sport. Traumatol. Arthrosc. 2011; 19(11):1955-61. https://doi.org/10.1007/s00167-011-1518-9.

55. Gardner EMH, VonderHeide N, Fisher R, Brooker G, Yates PJ. Effect of hydrogen peroxide on human tendon allograft. Cell Tissue Bank. 2013;14(4): 667-71. https://doi.org/10.1007/s10561-013-9377-x.

56. ISO 11137-3:2017(en) Sterilization of health care products — Radiation Part 3: Guidance on dosimetric aspects of development, validation and routine control. https://www.iso.org/obp/ui//\#iso:std:iso:11137:-3:ed-2:v1:en. Accessed 25 Mar 2021.

\section{Publisher's Note}

Springer Nature remains neutral with regard to jurisdictional claims in published maps and institutional affiliations.

Ready to submit your research? Choose BMC and benefit from:

- fast, convenient online submission

- thorough peer review by experienced researchers in your field

- rapid publication on acceptance

- support for research data, including large and complex data types

- gold Open Access which fosters wider collaboration and increased citations

- maximum visibility for your research: over $100 \mathrm{M}$ website views per year

At $\mathrm{BMC}$, research is always in progress.

Learn more biomedcentral.com/submissions 